J. Perinat. Med. $6(1978) 102$

\section{Ultrasonic recognition of two types of growth retardation by meas- urement of four fetal dimensions}

\author{
A. Kurjak, V. Latin, J. Polak
}

In recent years there has been a marked increase in the study and research effort directed towards growth retarded babies. The attention of both the obstetrician and pediatrician has focused on this problem because these babies have a high incidence of perinatal death and intrapartum asphyxia, and are at increased risk in the neonatal period from pulmonary hemorrhage, hypoglycaemia and fetal abnormality $[3,4,13]$. In the long term there is evidence that severely growth retarded babies suffer from intellectual impairment, especially if neonatal management is less than adequate [1]. Thus it is important to recognise these babies and the earlier in fetal life the better.

Increased sophistication of clinical and laboratory methods has enabled better antenatal detection and it is now widely accepted that serial ultrasonic biometry is the most accurate method for physically measuring fetal growth $[4,10,11,12,15,23]$. In a recent paper, Rosso and WINICK [25] supported the hypothesis that there are different types of infants with intrauterine growth retardation and that these different types can and should be recognised. Among ultrasonic workers, CAMPBELL [6], KuRJAK et al [15], and HANSMANN [10] described two different patterns of growth retardation which may be of importance in the short and long term prognosis of the fetus. However, no one has analysed this material in connection with perinatal complications of such problem babies.

We have reported our preliminary findings elsewhere [22] and in this paper we present our experience with ultrasonic recognition of these two types by measurement of four fetal dimensions.

\section{Curriculum vitae}

ASIM KURJAK was born in Kotor Varos, Yugoslavia in 1942 and graduated in 1966 from the University of Zagreb Medical School. He joined the staff of the University Gynecological Hospital in Zagreb in 1969 and was appointed assistant in the Medical School in 1970. In 1972 he spent ten months at the Institute of Obstetrics and Gynecology of the University of London and studied ultrasonic diagnosis and active management of labour. He is now head of the Ultrasonic Center in Zagreb. He is editor of the first Yugoslav book on "Ultrasound in Clinical Medicine", published in 1977, with internationally well-known contributers. He is particularly interested in ultrasound diagnosis, active management of labour and other perinatal problems.

\section{Patients and methods}

During a period of 27 months we examined at our Ultrasonic Center 7,143 patients with normal and complicated pregnancies. Among them, we found 118 small-for-dates babies who were classified according to the tables of THOMPSON et al [28]. Corrections were made for maternal parity and fetal sex. The few cases that delivered before 32 weeks gestation were grouped according, to GRUENWALD's tables [8]. Birthweights above the tenth percentile were classified as normal and those on or below the tenth percentile as smallfor-dates. The antenatal diagnosis of small-fordates fetuses was based on measurements of four fetal dimensions. 


\subsection{Serial ultrasonic cephalometry}

By using CAMPBELL's method [2] we measured the fetal biparietal diameter on the Diasonograph NE 4102 with the ultrasonic caliper speed of $1.600 \mathrm{~m}$ per second. Growth rates were categorized by reference to our two graphs illustrating the growth of the normal fetal biparietal diameter [16]. The first graph shows the normal range of the fetal biparietal diameter for each week of pregnancy and the second indicates the weekly growth rates of the fetal biparietal diameter (with percentile limits) according to the size of the fetal head. The method of classifying each patient into a percentile ultrasonic growth rate category is described elsewhere [14]. In this study ultrasonic growth rates were classified as (normal above the fif th percentile) and retarded (fifth percentile or less). Attention was focused on recognizing different patterns of

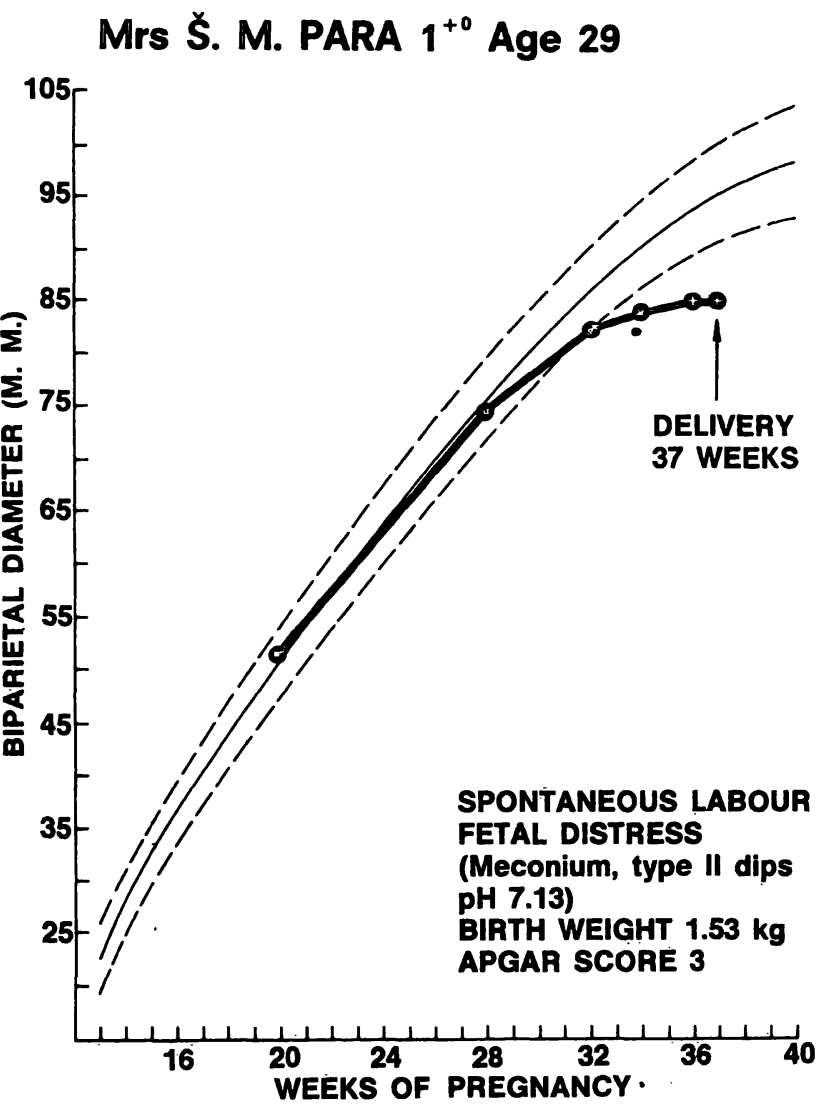

Fig. 1. Individual cephalometry chart superimposed on the normal range, showing typical asymmetrical growthretardation pattern associated with maternal hypertension, intrapartum fetal distress and low Apgar score. The birthweight $(1.53 \mathrm{~kg})$ was below the 5 th percentile for gestation. intrauterine growth retardation. These patterns fell into two main groups. In the first group there is a lengthy period of normal growth which is then usually followed by an abrupt flattening of the growth rate in the third trimester. A typical example of this asymmetrical pattern is illustrated in Fig. 1.

In the other growth pattern group the charts show a steady but abnormally low growth rate, usually early in the second trimester. An example of this symmetrical type of growth ratardation is illustrated in Fig. 2.

\subsection{Crown rump measurements of embryo}

To assess the embryonic size, growth and maturity in the first trimester, we measured the embryonic crown rumplengthessen tially following ROBINSON's technique [24]. We used our own graphs of normal values [21].

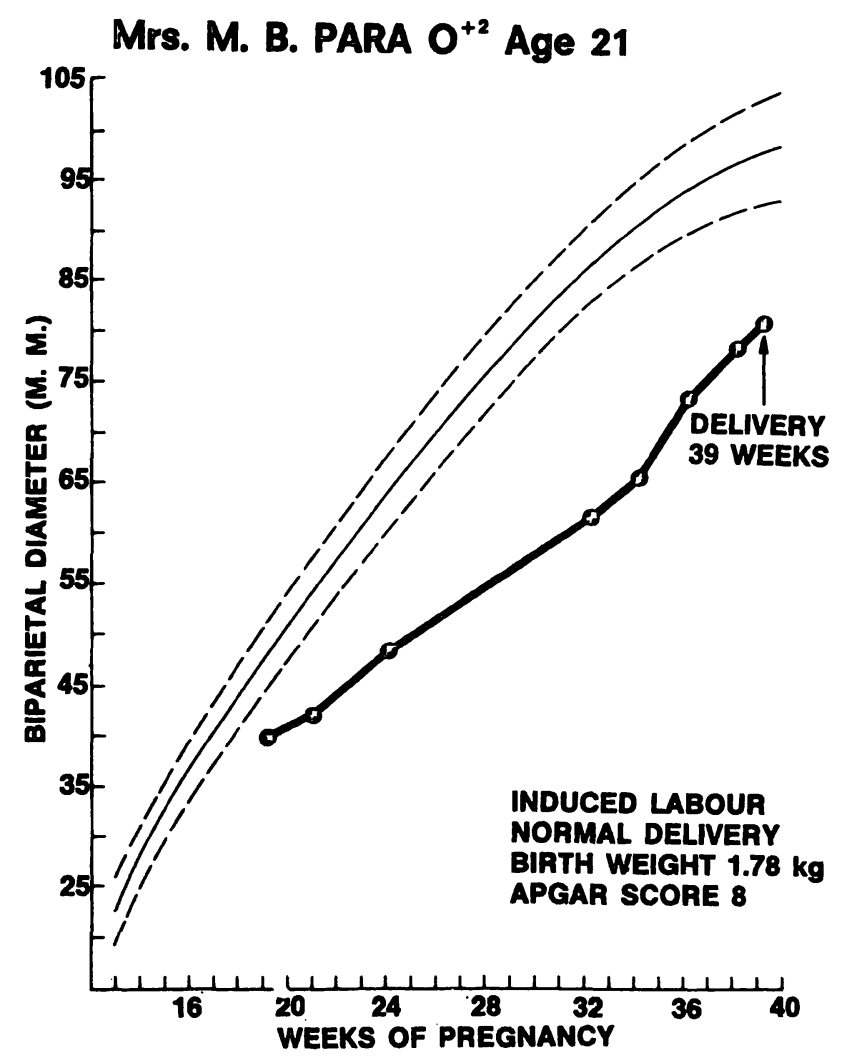

Fig. 2. Example of cephalometry in symmetrical growthretardation pattern. No intrapartum fetal distress was detected and the Apgar score was 10 at 5 minutes. The baby was mature by the pediatricians assessment. Birth weight was below the 5 th percentile for gestation. 


\subsection{Fetal abdominal circumference measurements}

For predicting fetal weight, we have settled on a measurement of the abdominal circumference at the level of the umbilical vein. Recently we introduced our own simple technique measuring the largest and shortest diameter and calculating the abdominal circumference by means of a formula. This technique and the initial results have been described elsewhere [20].

Another measurement of considerable value was the ratio of the circumference of the head to that of the abdomen, especially if the section is taken through the fetal liver.

\subsection{Fetal urinary production rate}

We used CAMPBELL's [5] recent technique of measuring three diameters and calculating the bladder volume from a formula. The hourly fetal urinary production rate was measured by taking two fetal bladder volume measurements at intervals of thirty minutes or an hour during the process of bladder filling and calculating the rate of increase over this period. We used our own normal values [17].

\subsection{Fetal criteria}

Differences between the two patterns of small-fordates babies were evaluated in relation to the following criteria of fetal well-being:

a) The one minute APGAG score. Cases of gross fetal abnormalities were excluded. APGAR scores of seven or more were regarded as normal while those below seven were classified as abnormal. b) The number of gross fetal abnormalities.

\section{Results}

A total of 118 small-for-dates babies were assessed by ultrasonic biometry. Ninety-four $(80 \%)$ of them followed the asymmetrical pattern of growth retardation while 24 (20\%), the symmetrical pattern. The obstetrical complications in the patients studied are listed in Tab. I. There was a significant increase in the incidence of hypertensive disorders in the group of asymmetrically growth
Tab. I. Incidence of pregnancy complications in the 118 small-for-dates babies.

\begin{tabular}{|c|c|c|c|}
\hline \multirow[t]{2}{*}{ complication } & \multirow{2}{*}{$\begin{array}{l}\text { total } \\
\text { cases* }\end{array}$} & \multicolumn{2}{|c|}{ pattern of growth-retardation } \\
\hline & & asymmetrical & symmetrical \\
\hline EPH gestoses & $31(26 \%)$ & 28 & 3 \\
\hline $\begin{array}{l}\text { essential hyper- } \\
\text { tension }\end{array}$ & $18(15 \%)$ & 16 & 2 \\
\hline $\begin{array}{l}\text { recurrent ante- } \\
\text { partum hemor- } \\
\text { rhage }\end{array}$ & $10(8.5 \%)$ & 6 & 4 \\
\hline $\begin{array}{l}\text { clinically small- } \\
\text { for-dates }\end{array}$ & $20(17 \%)$ & 15 & 5 \\
\hline $\begin{array}{l}\text { previous small- } \\
\text { for-dates }\end{array}$ & $8(7 \%)$ & 3 & 5 \\
\hline $\begin{array}{l}\text { height below } \\
150 \mathrm{~cm}\end{array}$ & $2(1.5 \%)$ & - & 2 \\
\hline $\begin{array}{l}\text { age over } 35 \\
\text { years }\end{array}$ & $7(6 \%)$ & 6 & 1 \\
\hline postmaturity & $6(5 \%)$ & 6 & - \\
\hline $\begin{array}{l}\text { no complic- } \\
\text { ations }\end{array}$ & $22(19 \%)$ & 12 & 10 \\
\hline
\end{tabular}

* Some patients had more than one complication

ratarded babies $\left.(2 \mathrm{P}<0.05) \chi^{2}=5.3\right)$ when compared with infants classified as symmetrical.

\subsection{The one minute APGAR score}

There were 107 small-for-dates babies in whome the one minute APGAR score was considered to reflect fetal hypoxia induced by the stress of labour or delivery (Tab. II).

The APGAR score was depressed (i.e. six or less) in $33(36 \%)$ of asymmetrically retarded babies and in two (13\%) of the 16 symmetrically retarded newborns. The difference in the number of low

Tab. II. APGAR score in growth retarded babies.*

\begin{tabular}{lcc}
\hline pattern of retardation & \multicolumn{3}{c}{ APGAR score } \\
& $\mathrm{X} \times 6$ & $\ldots \geqslant 7$ \\
\hline symmetrical $\mathrm{n}=16$ & $2(13 \%)^{+}$ & $14 .(87 \%)$ \\
asymmetrical $\mathrm{n}=91$ & $33(36 \%)$ & $58(64 \%)$
\end{tabular}

* Excluded 11 fetuses with gross fetal malformations. $+X^{2}=3.49$. $2 P>0.05$ 
APGAR scores between the asymmetrical and the symmetrical groups is not statistically significant $\left(X^{2}=3.49 .2 P>0.05\right)$.

\subsection{Fetal abnormality}

There were 11 gross fetal abnormalities. Two were microcephalics, one had renal agenesis and the remainder had multiple skeletal and central nervous system defects. Eight of the abnormal babies were in the symmetrical group, while only three (3.3\%) were in the asymmetrical group (Tab. III). However the number of investigated cases is too small for statistical analysis.

Tab. III. Incidence of gross fetal malformations in growth retarded babies.

\begin{tabular}{|c|c|}
\hline pattern of retardation & $\begin{array}{l}\text { number and percent of } \\
\text { malformed babies }\end{array}$ \\
\hline symmetrical $=24$ & $8(33 \%)$ \\
\hline asymmetrical $=94$ & $3(3.2 \%)$ \\
\hline$=118$ & $11(9.3 \%)$ \\
\hline
\end{tabular}

\subsection{Diagnostic accuracy of ultrasonic biometry}

In all cases serial ultrasonic cephalometry was performed, and 101 (86\%) out of 118 small-fordates babies were recognised with this technique.

The assessment of gestational age by measurement of embryonic crown rump length were performed in 34 small-for-dates babies. This was very useful in cases of symmetrical growth retarded babies where precise knowledge of the gestational age was essential.

In 46 small-for-dates babies the fetal weight was predicted by measuring the abdominal circumference. The difference between expected and real weight was within 269 grams in $95 \%$ of the investigated cases.

In 44 babies the head to abdomen circumference ratio was calculated. This ratio was greater than 1 in 36 cases and all of them were in the asymmetrically growth retarded group. In the remaining 8 symmetrically retarded babies, the ratio in three cases 1 and in four cases nearly 1 . Only one symmetrically retarded baby had a ratio greater than one.

The hourly fetal urinary production rate was measured in 32 small-for-dates babies. Twenty-nine $(91 \%)$ had reduced urinary production values. There was no difference between the two groups of retarded babies.

\section{Discussion}

From our results it can be concluded that there are two main types of growth retarded fetuses distinguishable by antenatal ultrasonography. The late growth retardation pattern is frequently associated with conditions which cause reduced placental perfusion, such as EPH gestoses and hypertension. They have a typical wasted appearence and are underweight for their height (Fig. 3). In this group there is a tendency to perinatal asphyxia, the APGAR score is low and there is an increased brain to liver ratio. This type is probably the result of uteroplacental vascular insufficiency, as described by WiNick [29].

The symmetrical retardation pattern, which occurred in $20 \%$ of our small-for-dates babies, results from prolonged growth impairment commencing early in the second trimester, even from 18 weeks. There is proportionate reduction in the fetal head, body length and body weight (Fig. 4) but growth does not usually stop. This type is not usually associated with EPH gestoses or intrapartum asphyxia. Such growth failure has been achieved in experimental animals by restriction of the mother's protein or calorie intake [25]. Some of these babies have genetic or chromosomal abnormalities and could

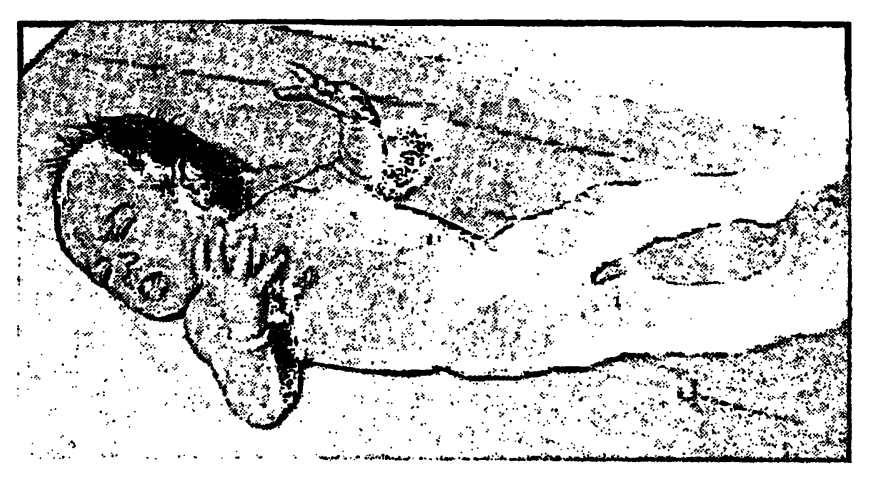

Fig. 3. Infant born at 38 weeks gestation, weighing $1.72 \mathrm{~kg}$ and showing ultrasonic and clinical characteristics of asymmetrical growth-retardation. 


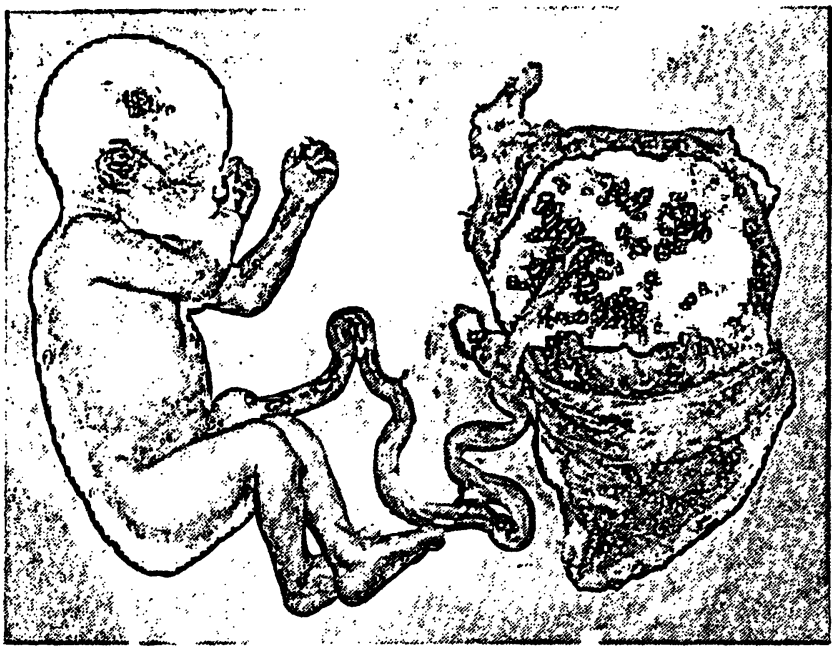

Fig. 4. Infant born at 37 weeks of gestation, weighing $1.58 \mathrm{~kg}$ and showing ultrasonic and clinical characteristics of symmetrical growth-retardation.

be examples of reduced growth potential. Long term follow-up of these babies has shown that prolonged intrauterine growth restriction causes stunting of growth in childhood and probably up to adulthood, and a significantly reduced general development quotient [7].

Although by cephalometry alone we can obtain important information relating to the future development of babies, it is now our practice to perform other fetal measurements to assess fetal maturity, growth rate and size at birth. The best measurement for assessing gestational age is the crown rump length of the embryo during the first trimester of pregnancy using RoBINSON's method. By means of this technique gestational age was determined within \pm six days in $95 \%$ of investigated cases [19]. After that period serial cephalometry was then performed to assess growth rate. It is well known that cephalometry is not an accurate predictor of birth weight and in recent years many authors have recommended the measurement of the fetal thorax or abdomen $[9,10,20$, $26,27]$. Wehave found the abdominal circumference to be reliable in everyday routine practice [20].

Another index of possible value is the ratio of head toabdominal circumference. In our symmetrically retarded babies this ratio was normal or nearly normal. This work is still in its early stages, but it seems to us that this ratio could provide a valuable means of distinguishing between the two types of growth retarded babies.

Finally, measurement of the fetal bladder shows that nearly all small-for-dates babies have reduced urine production, indicating an association between fetal growth retardation and reduced fetal renal function $[18,30]$, but without any difference between the two types of growth-retarded fetuses.

\section{Summary}

In a recent paper, ROSSO and WINICK [25] supported the hypothesis that there are different types of infants with intrauterine growth-retardation and that these different types can and should be recognized. In an analysis of 7,143 ultrasonic charts, two different patterns were found which may be of importance in the short and long term prognosis for the fetus. In the first group there is a sudden reduction of the growth rate following an of ten lengthy period of normal growth, resulting in disproportionate wasting of the trunk compared with the head. This asymmetrical pattern of growth retardation is frequently associated with conditions which cause reduced placental perfusion, such as EPH gestosis and hypertension (Tab. I). Typical examples are illustrated in Figs. 1 and 3.

In the second, symmetrically wasted group there is a persistently low growth rate from early in the second trimester, but usually without cessation. This growth retardation pattern usually results in a very small baby whose biparietal diameter is smaller in relation to birthweight than occurs with late growth retardation. Figs. 2 and 4 illustrate typical examples of symmetrically growth retarded babies. Of 118 small-for-dates babies measured

by ultrasound, 20 percent were found to be symmetrical growth retarded. The babies with asymmetrical growth retardation showed a high incidence of perinatal asphyxia as judged by APGAR scores (Tab. 'II). The incidence of gross fetal malformations was much higher in the symmetrical pattern group (Tab. III).

Although by cephalometry alone it was possible to recognise two different types of fetal growth retardation, the measurement of other fetal dimensions have been performed. The plan for better detection of such problem babies includes the measurements of embryonic crownrump length in the first trimester, serial ultrasonic cephalometry, abdominal circumference, ratio of head to abdominal circumference, and fetal bladder volume. To distinguish between the two types of growth retardation the best index was the ratio of head to abdominal circumference. This ratio was calculated in 44 investigated babies. The ratio was greater than one in 36 cases, all with asymmetrical growth retardation. In the remaining eight symmetrically retarded babies, the ratio in three cases was one and in four cases was nearly one. Only one symmetrically retarded baby had a ratio greater than one.

Keywords: Fetus, growth, growth retardation, ultrasonic biometry. 


\section{Zu sammenfassung}

Echographische Erkennung von Wachstumsretardierungen durch Bestimmung von 4 fetalen Meßgrößen.

ROSSO und WINICK [25] unterstützten in einer kürzlich erschienenen Arbeit die Meinung, daß es zwei verschiedene Arten von Kindern mit intrauteriner Wachstumsretardierung gäbe und daß diese verschiedenen Typen erkannt werden können und sollten. Bei der Analyse von 7143 Ultraschalluntersuchungen wurden 2 verschiedene Wachstumsmuster gefunden, die möglicherweise für die kurzund langfristige Prognose des Feten von Bedeutung sind. In der ersten Gruppe findet sich ein plötzlicher Rückgang der Wachstumsrate nach einer oft langen Periode normalen Wachstums. Ein typisches Beispiel dieses asymmetrischen Wachstumsverhaltens zeigt $\mathrm{Abb}$. 1. Diese asymmetrische Form der Wachstumsretardierung war häufig mit Bedingungen verbunden, die eine reduzierte plazentare Perfusion verursachen wie EPH-Gestose und Hypertonie (Tab. I). Abb. 3 illustriert das typische, Erscheinungsbild solcher Kindern.

In der zweiten Gruppe (Abb. 2) zeigen die Wachstumskurven vom frühen Beginn des 2. Trimesters an eine anhaltende, geringe Wachstumsrate, in der Regel ohne Tendenz zum Wachstumsstillstand. Diese Art der Wachstumsretardierung war mehrheitlich verbunden mit einem sehr kleinen Kind, dessen biparietaler Durchmesser im Verhältnis zu seinem Geburtsgewicht kleiner war als jener der Kinder mit spät einsetzender Wachstumsretardierung. Abb. 4 zeigt das typische Beispiel eines Neugeborenen mit symmetrisch retardiertem Wachstum. Die
Daten von 118 durch Ultraschall diagnostizierten smallfor-dates Kinder wurden analysiert, wobei sich $22 \%$ Neugeborene fanden mit symmetrischer Wachstumsretardierung. Die Neugeborenen der Gruppe mit asymmetrischer Wachstumsretardierung hatten einen hohen Anteil von perinataler Asphyxie (Tab. II). In der Gruppe mit symmetrischer Retardierung war die Häufigkeit grober fetaler Mißbildungen erheblich höher (Tab. III). Auch die Vermessung anderer fetaler Größen wurden durchgeführt, obwohl es allein durch Kephalometrie möglich war, zwei verschiedene Arten fetaler intrauteriner Wachstumsretardierungen zu diagnostizieren. Maßnahmen zur besseren Erkennung solcher Problemkinder beinhalten die Vermessung der embryonalen ScheitelSteißlänge im ersten Trimester der Schwangerschaft, die fortlaufende UltraschallKephalometrie, Messung des Bauchumfanges, des Quotienten aus Kopf- und Abdominalumfang und das fetale Blasenvolumen.

Für die Erkennung der beiden erwähnten Arten von Wachstumsretardierung war die Bestimmung des Quotienten von Kopf- und Bauchumfang am ergiebigsten. Dieser Quotient wurde in 44 untersuchten Fällen errechnet. Der Quotient betrug mehr als 1 bei 36 Fällen, von denen alle Probanden jener Gruppe mit asymmetrischer Wachstumsretardierung angehörten. Bei den verbleibenden 8 Fällen mit symmetrischer Retardierung betrug der Quotient in 3 Fällen 1 und nahezu 1 in vier Fällen. Nur 1 Kind mit symmetrischer Retardierung hatte einen Quotienten über 1.0.

Schlüsselwörter: Fetus, Ultraschallbiometrie, Wachstum, Wachstumsretardierung.

\section{Résumé}

Dépistage par ultrason de deux formes-types du retardement de la croissance par la mesure de quatre dimensions foetales

Dans un article récent ROSSO et WINICK [25] ont établi l'existence et la nécessité de reconnaître l'existence de formes-types différentes du retardement de la croissance intrautérine.

L'analyse de 7.143 tableaux ultrasonores a permis de définier deux modèles différents dont l'importance pourrait être grande pour le pronostic à long et court terme du foetus. Le premier groupe, avec une pçriode souvent longue de croissance normale, montre une baisse soudaine du taux de croissance. La fig. 1 illustre un exemple typique de ce modèle asymétrique du retardement de la croissance qui est fréquemment associé à des conditions provoquant une perfusion placentaire réduite telle qu'une gestose $\mathrm{EPH}$ et l'hypertension (tab. I). La fig. 3 illustre un aspect d'affaiblissement typique de tels bébés.

Dans le second groupe modèle (fig. 2), les tableaux montrent un taux de croissance continuellement bas dès le début du second trimestre, généralement sans tendance de cessation de croissance. Ce modèle de retardement de la croissance a donné souvent un très petit bébé dont le diamètre bipariétal est plus petit par rapport au poids de la naissance que dans les cas de retardement tardif de la croissance. La fig. 4 illustre un exemple typique de croissance symétrique de bébés retardés. On a analy sé les résultats enregistrés par ultrason pour 118 bébés immatures et constaté 22 pour cent de croissance symétrique de bébés retardés. Les bébés relevant du groupe modèle de retardement asymçtrique de la croissance ont montrç une incidence élevée d'asphyxie périnatale ainsi qu'on a pu en juger par un nombre de scores Apgar bas (tab. II). L'incidence de malformations foetales macroscopiques beaucoup plus élevée dans le groupe modèle symétrique (tab. III).

Bien qu'il ait été possible de déceler deux formes-types différentes de retardement de la croissance foetale par la seule céphalométrie, on a effectué la mesure d'autres dimensions foetales. Le programme d'un meilleur dépistage des bébés présentant de telles difficultés implique aussi, en effet, les mesures de la longueur du sommet de siège embryonnaire au premier trimestre, de la céphalométrie ultrasonore sérielle, de la circonférence abdominale, du rapport de circonférence de la tête à l'abdomen et du volume de la vessie du foetus. La meilleure valeur pour le dépistage des deux formes-types mentionnées a été la mesure du rapport de circonférence de la tête à l'abdomen. 
Ce rapport a été calculé chez 44 bébés. Il a dépassé un dans 36 cas qui ont tous fait partie du groupe retardé ą croissance asymétrique. Chez les 8 bébés restants, symétriquement retardés, le rapport a été de un dans 3 cas et de presque un dans 4 cas. Seulun bébé symétriquement retardé a enregistré un rapport supérieur à un.

Mots-clés: Biométrie ultrasonore, croissance, foetus, retardement de la croissance.

\section{Bibliography}

[1] BARD, H.: Intrauterine growth retardation. Clin. Obstet. Gynaecol. 13 (1970) 511

[2] CAMPBELL, S.: An improved method of fetal cephalometry by ultrasound. J. Obstet. Gynaec. Brit. Cwlth. 75 (1968) 568

[3] CAMPBELL, S., C. J. DEWHURST: Diagnosis of the small-for-dates fetus by serial ultrasonic cephalometry. Lancet (1971) II, 1002

[4] CAMPBELL, S., A. KURJAK: Comparison between urinary oestrogen assay and serial ultrasonic cephalometry in assessment of fetal growth retardation. Brit. Med. J. (1972) IV, 336

[5] CAMPBELL, S., J. W. WLADIMIROFF, C. J. DEWHURST: The antenatal measurement of fetal urine production. J. Obstet. Gynaecol. Brit. Cwlth. 80 (1973) 680

[6] CAMPBELL, S.: Fetalgrowth. Clin. Obstet. Gynaecol. 1 (1974) 41

[7] CAMPBELL, S.: Discussion at the 5th European congress of perinatal medicine, 10th June-Uppsala (1976)

[8] GRUENWALD, P.: Growth of the human fetus. 1. Normal growth and its variation. J. Obstet. Gynec. 94 (1966) 1112

[9] HANSMANN, M.: U. VOIGT, H. BAEKER: Die Wertigkeit intrauterin mit Ultraschall meßbarer Parameter für die Gewichtsklassenschätzung des Feten. Arch. Gynäk. 214 (1973) 314

[10] HANSMANN, M.: Fetalna torakometrija, In: Dijagnostički ultrasvuk: A.KURJAK, Medicinske nakladeZagreb 1976

[11] HÖLLANDER, H. J.: Die Ultraschalldiagnostik in der Schwangerschaft. Urban und Schwarzenberg, Berlin-München 1975

[12] KRATOCHWIL, A.: The state of ultrasound diagnosis in perinatal medicine. J. Perinat. Med. 3 (1975) 75

[13] KURJA K, A., E. BARŠIC, V. GORECAN, V. LATIN: Porodbeni studiji perinatalne smrtnosti $u 1124$ nedonoščeta i nedosteščeta. In: A. DRAŽANČIĆ: Perinatalni dani, Zagreb 1974

[14] KURJAK, A., B. RAJHVAJN, A. DRAŽANČÍ́, V. LATIN, E. BARŠIĆ: The assessment of fetal wellbeing in late pregnancy by serial ultrasonic cephalometry. Proceedings of the 4 th European Congress of Perinatal Medicine, Praha 1974 (in press)

[15] KURJAK, A., A. DRAŽANČIĆ, I. OLAJOŠ, V. LATIN, I. KUVAČIĆ, J. POLAK: Ultrazvð̌na biometrija u nadzoru intrauterinog rasta ploda. In: A. DRAŽANČ́ı́́) Perinatalni dani, Zagreb 1974

[16] KURJAK, A.: Utvrdjivanje zrelosti i rasta ploda biparijetalnom kefalometrijom s pomoću ultrazvuka. Dissertation theme. Zagreb 1975
[17] KURJAK, A., D. IVANKOVIĆ: Ultrazvučna mjerenja islučivanja fetalne mokraće u normalnoj trudnoći. Jugoslav. ginek. opstet. 15 (1975) 49

[18] KURJAK, A., V. LATIN: Ultrasonic evolution of fetal renal function in EPH gestosis. IRCS Medical Science. 3 (1975) 9

[19] KURJAK, A., S. ČČUK, B. BREYER, I. OLAJOŠ: Odredjivanje gestacijske dobi u prvom tromjesećju ultrazvucnim mjerenjem odjeka embrija. Acta med. iug. 29 (1975) 339

[20] KURJAK, A., B. BREYER: Prediction of fetal weight by ultrasonic abdominometry. Amer. J. Obstet. Gynec 125 (1976) 962

[21] KURJAK, A., S. ČĚ̌UK, B. BREYER: Prediction of maturity in first trimester of pregnancy by ultrasonic measurement of fetal crown-rump length. J. Clin. Ultrasound. 4 (1974) 83

[22] KURJAK, A., V. LATIN, V. SIMUNIC: Ultrasonic recognition of two types of growth-retardations by measurement of four fetal dimensions. Paper read at the 5 th European Congress on Perinatal Medicine. Book of abstracts No. 63. Uppsala 1976

[23] LEVI, A., P. SMETS: Intrauterine fetal growth studied by ultrasonic biparietal measurements. Acta Obstet. Gynec. Scand. 52 (1973) 193

[24] ROBINSON, H. P.: Sonor measurement of the fetal crown rump length as means of assessing maturity in the first trimester of pregnancy. Brit. med. J. 4 (1973) 28

[25] ROSSO, P., M. WINICK: Intrauterine growth retardation. A new systematic approach based on the clinical and biochemical characteristics of this condition. J. Perinat. Med. 2 (1974) 147

[26] SCHLENSKER, K. H.: Eine Ultraschallmethodik zur Thorakometrie beim Feten. Geburtsh. u. Frauenheilk. 33 (1973) 440

[27] STÖGER, H., A. KRATOCHWIL: Ultraschallbiometrie des fetalen Wachstums. Geburtsh. u. Frauenheilk. 34 (1974) 611

[28] THOMSON, A.M., W.Z.BILLEWICZ,F.E.HYTTEN: The assessment of fetal growth. J. Obstet. Gynacol. Brit. Cwlth. 75 (1968) 903

[29] WINICK, M.: Cellular growth of the placenta as an indicator of abnormal fetall growth. In: ADAMSONS, K.: Diagnosis and treatment of fetal disorders. Springer, New York 1969

[30] WLADIMIROFF, J., S. CAMPBELL: Fetal urine production rates in normal and complicated pregnancy. Lancet 1 (1974) 151

Received July 17, 1976. Accepted November 10, 1977.

Dr. Asim Kurjak

Ultrasonic Center, Dept. of Obstetrics and Gynecology, Medical Faculty, University of Zagreb, Yugoslavia Petrova 13 